Acta Universitatis Nicolai Copernici • Pedagogika XXXV/1/2018

Nauki Humanistyczno-Społeczne • Zeszyt 445

DOI: http://dx.doi.org/10.12775/AUNC_PED.2018.007

\title{
Ewa Sowa-Behtane
}

Jesuit University Ignatianum in Cracow

ORCID: 0000-0002-0190-0567

\section{The ASSERTIVENESS IN THE PROCESS \\ OF TRANSFORMATION OF IDENTITY \\ IN MULTICULTURAL MARRIAGES}

\begin{abstract}
In this article, assertiveness will be presented as an important and even essential spousal ability used in the process of identity transformation in marriages, to condition the correct and satisfying functioning of a multicultural relationship for each of them. Assertiveness is a necessary skill, especially when marriages come from people whose expectations may differ significantly in many spheres of marital life due to their cultural identity.

Ke y w ord s: assertiveness, cultural identity, identity transformation, multicultural marriages.
\end{abstract}

ASERTYWNOŚĆ W PROCESIE TRANSFORMACJI TOŻSAMOŚCI W MAEŻEŃSTWACH WIELOKULTUROWYCH

\section{Streszczenie}

W niniejszym artykule asertywność zostanie przedstawiona jako ważna, a nawet niezbędna, umiejętność małżonków, wykorzystywana w procesie transformacji tożsamości w małżeństwach, warunkująca poprawne i satysfakcjonujące, 
dla każdego z nich, funkcjonowanie związku wielokulturowego. Asertywność jest konieczną umiejętnością szczególnie w sytuacji, gdy w związek małżeński wchodzą osoby, których oczekiwania mogą różnić się znacznie w wielu zakresach życia małżeńskiego ze względu na ich tożsamość kulturową.

Słowa kluczowe: asertywność, tożsamość kulturowa, transformacja tożsamości, małżeństwa wielokulturowe

\section{Introduction}

Tn the era of globalisation, meeting people from different cultural cirIcles on one's way through life has become a common phenomenon. Nowadays, mostly due to the Internet and increasingly easier communication between various countries, we are observing the so-called "shrinking" of the world, with a consequent increase in the number of people who fall in love with people from distant countries and get involved with them on a permanent basis. Accordingly, couples of mixed cultures are increasingly becoming a subject of scientific research.

When people from separate cultures join together to make a couple, it is very important to preserve their own cultural identity. In young multicultural marriages, identity begins transformation, which lasts until the end of the marriage. At this time, they determine the following: marital topics; marital roles and responsibilities; compliance with the matrimonial identities; strategies that regulate distance with family, friends or work; strategies regarding internal borders between spouses; household and financial management strategies; strategies for achieving sexual satisfaction and strategies for managing a potential conflict. The assertiveness is helpful in this situation.

\section{Cultural identity}

Zygmunt Bauman wrote that "The idea of 'identity' was born from the crisis of belonging, the desire to build a bridge between what 'belongs' and what 'is', raise and transform reality to standards and the similar- 
ity of this idea" . Cultural identity is currently a very current research topic. Identity is a social category understood in general terms as showing to other individuals and to we ourselves an identity; that is, identifying with some elements of social reality, as well as enabling others to identify them².

As Tadeusz Paleczny wrote, "every man comes from somewhere, is born somewhere. The personality of each individual is shaped in a small, local, family-neighborly community. Before we achieve a sense of belonging to a larger cultural group, such as an ethnic, racial or national group, we identify with our closest surroundings - with family, relatives and neighbors. We first acquire identification with our 'private' homeland. We accept as our own dominant set of symbols transmitted by the family environment. Internalisation of norms and symbols forms our worldviews. The family bond, local, transforms in the consciousness of individuals, groups into patriotism, nationalism, generalises in a sense of connection with the ideological homeland"3.

Therefore we will distinguish individual and collective identity. Cultural identity is considered as the most important kind of collective identity, which "is based on a historically conditioned, cultural way of preserving the existence and continuity of a species and biopsychic balance by a given human group"4. Its components are: "(...) 1) elements of heritage, even completely or partially obsolete, 2) the type, proportions and structure of the constituent elements of a given culture, both due to the distinctiveness of cultural characteristics and the level of socioeconomic universals achieved and civilisational within a given culture, 3 ) the external context of equivalent or inequalities of contacts with other cultures, occurring at varying levels in the past and present" ${ }^{\text {. }}$

1 Z. Bauman, Tożsamość. Rozmowy z Benedetto Vecchi, transl. J. Łaszcz, Gdańsk 2007, p. 22.

2 K. Olechnicki, P. Załęcki, Słownik Socjologiczny, Toruń 1997, p. 228.

3 T. Paleczny, Interpersonalne stosunki międzykulturowe, Cracow 2007, p. 47-48.

${ }^{4}$ K. Kwaśniewski K., Tożsamość społeczna i kulturowa, In: Słownik Etnograficzny, edited by Z. Staszczak, Warsaw-Poznan 1987, p. 351.

5 Ibid., p. 351-352. 
In the literature on the subject, in relation to cultural identity, we find a very important position, which is represented by Wolfgang Welsch, the creator of the concept of transculturality, which claims that "work on one's identity is increasingly becoming a work on the integration of many composers of different cultural origins" ${ }^{\text {" Formation }}$ of identity is made today not on the basis of some own, homogeneous, native culture, but instead due to the mixing of the influence of many cultures whose provenance at some point becomes impossible to trace. Referring to the typology of socio-cultural identity, we can state that we have found ourselves on the level of the global identity of humanity. It is difficult to talk about national identities (German, Polish, etc.) that have long been replaced by post-national identities (civilisations: Western, Latin American, African, Islamic, etc.). Civilisations, in turn, are an intermediate state leading to the disseminating and universalisation of world identity to all humanity producing transcultural identity.

With this theoretical approach, the cultural identity of children functioning in multicultural families can be considered. From birth, these units are in a situation that can be defined by a kind of borderland, which can contribute to the emergence of new types of cultural identities ${ }^{7}$. It seems that people of such a heterogeneous national origin who had contact with the cultures of both parents, are a leaven of new awareness to the extent that, for them, national identity will, in the overall structure of individual identity, eventuallly lose its meaning $^{8}$. As Tadeusz Paleczny writes, in a culturally mixed environment, in which there is a clear tendency to combine, synthesise and create a new, wider group identity of the cultural whole, the chance of crossing religious, linguistic or racial barriers increases. It is a long-lasting process, encompassing various variants of mutual adaptation, accultur-

6 W. Welsch, Transculturalism. A new concept of culture, In: Philosophical contexts of the concept of transversal reason. Around the concept of Wolfgang Welsch, edited by R. Kubicki, Poznań 1998.

7 T. Paleczny, Interpersonalne stosunki międzykulturowe, Cracow 2007, p. 87.

8 E. Nowicka, Dylematy potomków małżeństw narodowo mieszanych, "Contemporary Culture", 2005, no. 3, p. 115. 
ation, and amalgamation of people from different homelands, cultures, speaking different languages ${ }^{9}$.

It is not only among children from culturally mixed families, but also among multicultural marriages, that the boundaries between ethnic, national, racial and civilisational identity are blurred. According to Grzegorz Babinski, "the universalisation of culture, the increasing transference or even the disappearance of state borders raise questions about the cultural identity of nations and nation states. The range of common values and cultural symbols is certainly widening, especially in the sphere of mass culture"10. On the other hand, in the new configuration of social, religious and cultural bonds, regional and local cultures are maintained and consolidated, connected with the existence of "nurseries", embedded and functioning more and more clearly in a multicultural space. These "private" thus homelands remain a crucial element of the cultural identity of individuals ${ }^{11}$.

\section{Types of functioning for members of multicultural marriages}

Referring to the two theories of shaping cultural identities presented above, i.e. the theory of transcultural identities and the universalisation of culture and the theory of returning to regional, national and "small fatherland" roots as a response to globalisation and universalisation of culture, the following types of functioning of multicultural marriages can be distinguished:

1. Observer or participant. The spouse-observer is an observer of the culture of his/her partner. He/she does not participate in cultivating traditions, customs, etc., but does not engage, just observes "from the outside". While, the spouse-participant participates in the culture of his/her partner "from the inside" and, for example, participates in cultivating traditions.

9 T. Paleczny, op.cit., p. 48.

10 G. Babiński, Pogranicze polsko-ukraińskie. Etniczność, zróżnicowanie religijne, tożsamość, Cracow 1997, p. 11.

11 T. Paleczny, op.cit., p. 49-50. 
2. Distance or commitment. The prospect of a spouse engaged in the culture of a partner provides them with the opportunity to truly accompany the implementation of cultural elements, being in interaction with the husband/wife. Approaching from a distance is not entering into a relationship of sympathy or fascination with the culture of a partner, keeping an appropriate distance.

3. Behavioural sphere or mental sphere. The behavioural sphere is the involvement only in the behaviour of a partner; for example, sharing a meal on the occasion of a partner's holiday, while the mental sphere is a commitment to thoughts and feelings. A spouse, getting to know the partner's feelings or thoughts will, for example, try to help him/her in a situation of oppression or suffering because of inequality, intolerance, exclusion or social injustice associated with being a representative of a given culture.

Everyone adopts a strategy for dealing with the culture of a partner, but regardless of how we treat the partner's culture in a marriage, problems may arise. Partner selection can have a significant impact on the relationship's durability and the number of problems in it. According to Jan Rostowski's statement, marriages with two cultures close to each other have a greater chance of success than those differing only in a national, racial and religious way ${ }^{12}$. The degree of cultural diversity determines the number of problems occurring between partners. Differences in nationality, religion, language and culture can affect marriage both negatively and positively ${ }^{13}$. The result is conditioned by many factors, but in this article, we will focus on the acceptance of a different partner culture.

\section{Assertiveness}

Assertiveness is a skill that is a condition for mature and effective communication. The term means the ability of a person to honestly, sustainably and accurately express their own thoughts, beliefs, experienc-

12 Ibid.

13 E. Sowa-Behtane, Rodziny wielokulturowe, Cracow 2016, p. 27. 
es and desires in a socially acceptable way, while granting other people the right to do the same. The basis of assertiveness is the belief that people can understand and respect someone's beliefs, needs or identity whenever they have the opportunity ${ }^{14}$. Assertiveness is an attitude that preserves and maintains the dignity of all participants of interpersonal contacts in social situations ${ }^{15}$.

According to the Association for Advancement of Behaviour Therapy, assertive behaviour is "a team of interpersonal behaviours expressing feelings, views, or rights of a person in a direct, decisive and honest way, while respecting the feelings, attitudes, opinions and rights of others. Assertive behaviour may include the expression of feelings such as anger, fear, commitment, hope, joy, despair, embarrassment and many others, but in each of these cases these feelings are expressed in a way that does not violate the rights of others and not hurts"16.

The situation in which someone expects others to guess what he or she is experiencing leads to misunderstandings, conflicts and disappointments. For this reason, assertiveness is a prerequisite for building clear and transparent interpersonal relationships. It is a tool for a good information flow between interlocutors. The test of assertiveness is the ability to defend your own righteous rights and your own identity, while respecting the legitimate rights and identities of other people. This is, among others, a difficult art of saying 'no' to almost all people in the face of requests, proposals or pressures that worry us or are contrary to our beliefs, moral principles or our hierarchy of values ${ }^{17}$.

Marek Dziewiecki lists the following principles of assertion informing interlocutors about ourselves ${ }^{18}$ :

14 M. Dziewiecki, Assertiveness and empathy and upbringing, "Catechist Formation Books", 2001, no. 1, p. 63.

15 M. Kornaszewska, Stopień asertywności a więzi w małżeństwie, "Studia nad Rodziną", 2008, no. 2, p. 133.

16 M. Król-Fijewska, Trening asertywności. Scenariusz i wywiad, Warsaw 1993, p. 9.

17 M. Dziewiecki, Empatia and assertiveness in education, http://www.marekdziewiecki.eu/images/www/teksty/new_teksty/empatia_i_asertywnosc_w_wychowaniu.pdf (accessed on 20/02/2017).

18 Ibid. 
1. should be expressed in the first person singular;

2. informing the interlocutor about our beliefs or experiences, it is worth telling about the circumstances or motives that affect what is happening in us. Then the listener will be easier to understand and respect our subjective way of looking and feeling;

3. take responsibility for the thoughts and emotions we are talking about to other people. It is therefore necessary to formulate statements about the subject, so that it is obvious to the listener that I am talking about my ways of thinking and experiencing and that I take responsibility for them.

The issue of assertiveness is usually considered in ten aspects. They concern: defence of one's own rights, personal contacts, initiatives in social contacts, expressing and accepting criticism and praise, expressing requests and needs, expressing feelings, public performances, contacts with authority, intrusions on other people's mental territories. Of these, the most important for the subject of the marital relationship were: personal contacts, the ability to express feelings and intrusion on other people's psychic territories because they characterise the marital relationship in a direct way ${ }^{19}$.

\section{Assertiveness in marriage}

The reality of marriage potentially involves the emergence of various conflicts that may happen when the wishes and expectations of one spouse are incompatible with those of the partner. The source of conflict is often stress, which can arise inside, but also outside the family. Stress within the family can be caused by developmental changes or other internal changes in the spouse (e.g. illness or disability). Stress arising outside the family caused, for example by work, can be transferred to the home and moved to the spouse as a "more secure" inch of anger discharge ${ }^{20}$. Multicultural marriages are additionally burdened due to cultural differences. In young multicultural marriages, identity

19 M. Kornaszewska, op.cit., p. 134.

20 M. Plopa, J. Rostowski, Questionna Mata Marriage (KDM-2), In: Ties in marriage and family. Research methods, ed. M. Plopa, Cracow 2008, p. 65. 
transformations lasts until the end of the marriage. At this time, they determine $^{21}$ :

- marital topics; The task of each pair of spouses is to determine marital and family topics. To do this, they must combine heritage and themes from their generational families. Each new married couple must develop marital and family themes that reflect the various ways of representing themselves outside the community. These topics relate to values, priorities or goals: "The topics often reflect the ethnic, religious and moral convictions of the family"22. By adopting topics of the generational family, people who create a new relationship often express their willingness to identify with the experiences of the former family in the form of cultivating the same holidays, customs, traditions, values, division of roles, etc. In general, they will be more willing to use these family themes in their marriages that relate to a sense of happiness. In some cases, one heritage takes precedence over the other: "This is the case, for example, when a spouse with other ethnic or religious roots adopts an ethnic or religious identity in the generational family. In other cases there are confused and compromise topics and identities, which in turn give new themes" 23 . When determining marital topics, the ability to behave assertively will be a condition for mature and effective communication in this area.

- marital roles and responsibilities; Married people have specific ideas and expectations about marital roles that are based on the experiences of their generational families. Being that the experiences of man and woman from culturally different generational families are different, there is a high probability that the spouses will have different ideas about their marital roles ${ }^{24}$. To ensure compliance and compromise in this matter, one should be assertive and negotiate his marriage roles until a common consensus is found.

${ }^{21}$ Ibid., p. 51-68.

22 Ibid., p. 52.

${ }^{23}$ Ibid., p. 53.

24 Ibid., p. 54-55. 
- compatibility regarding the marital identity. Knowledge of the partner's identity (his system of values, attitudes, ideology, religion, philosophy of life) allows for predicting his behaviour in specific situations. It can be predicted that, for example, a man professing Islam will not be interested in attending church services with his Catholic wife. Assertiveness in this situation should consist in honestly expressing his own thoughts and beliefs, while granting the right to the same to his spouse.

- strategies that regulate distance with family, friends or work. Strategies that the couple determines to regulate its external boundaries are influenced by two factors: boundary rules that exist in the generational family of each partner and the level of the process of individuation and separation from the generational family of each partner. For example, a family of English origin emphasising personal space and privacy will probably expect a newly separated marriage from a newly born marriage. The situation will be different if one or two of the spouses come from, for example, a Pakistani family, which assumes maintaining closeness and even interference in the relationship. Determining the external boundaries will help foster an assertive attitude through which the spouses can determine the expectations of visits to parents, sharing dinner together, the frequency of telephone conversations and the degree of initiation into intimate matters of marriage, etc.

- strategies regarding internal borders between spouses. These boundaries must allow each of the spouses to express their individuality and the possibility of realising themselves in a relationship. Setting internal boundaries should be strengthened by openness in clearly communicating the emotional needs of a person and the willingness of both partners to negotiate a balance in meeting these needs.

- household management strategies. A spouse who has more personal resources and who is less dependent on the relationship, usually seeks to have more power in it and to delegate duties with a lower statute for a spouse. A culturally patriarchal system (e.g. in the Arab countries) also gives more resources, such as higher status or better paid work to men, who thus have more 
power in marriage. The other factors creating the allocation of duties in the household are earlier gender socialisation, expectations for a relationship, a subjective sense of expertness in performing marital roles. The adequacy of these strategies is reflected in the level of satisfaction of the spouses, due to their use.

- financial management strategies. It consists in developing a proper relationship to the funds and bank accounts, and responsibility for the way of use financial resources. The problem may be more difficult if the spouses bring unequal financial resources to the union. In marriages in which partners have significant differences in personal or financial resources, an assertive attitude is particularly important, which maintains and maintains the dignity of all participants of interpersonal contacts, including those who have less.

- strategies for achieving sexual satisfaction. The sexual script has to be negotiated because the spouses can differently perceive the motives of having sex or interpret differently the needs and expectations of the partner in this regard.

- strategies for managing a potential conflict. Some couples, fearing marital conflicts, are looking for ways to avoid them. Other couples accept the inevitable conflicts and develop strategies to deal with them. These strategies include an open discussion about the conflict and assume negotiations. Strategies for conflict management arise in the models they have learned in generational families: "Conflict management strategies are further influenced by the importance of spouses ascribing conflict. Conflict in relationships is inevitable. Understanding this fact by the spouses and perceiving the conflict in terms of different ideas about its solution, and not in terms of an attack on personal identity, can facilitate the formation of constructive conflict management strategies that support more than inhibit the development of intimacy"25.

Assertiveness can be used to facilitate the expression of feelings, both positive and negative. Assertiveness supports the adoption of spe-

25 Ibid., p. 67. 
cific and decisive positions, which nevertheless encourage partners to negotiate solutions to problems and agree on a settlement ${ }^{26}$. Monika Kornaszewska, analyzing the results of her research among 86 married couples with the help of two tools: Maria Król-Fijewska Assertiveness Chart and Józef Szociński's Matrimonial Association Scale states that assertiveness has a major impact on relationships characteristic of marriages. This analysis also confirms the hypothesis that a high level of assertiveness of the respondents positively influences and builds favourably on their marital relationship. The results of the study clearly showed that the acceptance of the assertive attitude by the spouses causes the emergence of permanent, strong and happy bonds between them. Assertiveness turned out to be not only a collection of techniques and statements on how to defend ourselves against other people, but above all a philosophy of life and the "technology" of interpersonal contacts $^{27}$.

\section{Summary}

The barrier in accepting the cultural identity of a partner in a multicultural marriage is ethnocentrism, which is the belief in the 'superiority' of one's culture over the culture of a partner. It is expected then that the partner will adapt to our requirements and culture's interpretation of words, gestures and behaviours. As ethnocentric behaviour, the attempt to force the spouse to give up cultivating his/her traditions, customs, using his/her language or eating his national dishes may lead to disorders and changes in the cultural identity of that partner. Hence, to be able to preserve own identity in a multicultural marriage, assertiveness is necessary. In summary, when determining the afore-mentioned marriage strategies, the test of assertiveness is the ability to defend one's own righteous rights and one's own cultural identity, while respecting the legitimate rights and cultural identity of the spouse.

\footnotetext{
26 M. Kornaszewska, op.cit., p. 135.

27 Ibid., p. 140.
} 
Hence, assertiveness in a multicultural marriage is an indispensable skill for the satisfactory and correct functioning of two people.

\section{References:}

Babiński, Grzegorz. Pogranicze polsko-ukraińskie. Etniczność, zróżnicowanie religijne, tożsamość. Kraków: Nomos, 1997.

Bauman, Zygmunt. Tożsamość. Rozmowy z Benedetto Vecchi. Gdańsk: GWP, 2007.

Dziewiecki, Marek. "Assertiveness and empathy and upbringing". Catechist Formation Books 1 (2001): 49-63.

Dziewiecki, Marek. Empatia i asertywność w edukacji. http://www.marekdziewiecki.eu/images/www/teksty/new_teksty/empatia_i_asertywnosc_w_wychowaniu.pdf (accessed on 20/02/2017).

Kornaszewska, Monika. "Stopień asertywności a więzi w małżeństwie". Studia nad rodziną 2 (2008): 133-140.

Król-Fijewska, Maria. Trening asertywności. Scenariusz i wykłady. Warszawa: Instytut Psychologii Zdrowia PTP, 1993.

Kwaśniewski, Krzysztof. "Tożsamość społeczna i kulturowa”. In: Słownik Etnograficzny. ed. Zofia Staszczak 351-353, Warszawa-Poznań: PWN, 1987.

Nowicka, Ewa. "Rozdroże tożsamościowe. Dylematy potomków małżeństw narodowo mieszanych". Kultura Współczesna 3 (2005): 115-130.

Olechnicki, Krzysztof, Załęcki, Paweł. Słownik Socjologiczny. Toruń: Graffitti, 1997.

Plopa, Mieczysław, Rostowski, Jan. "Questionna Mata Marriage (KDM-2)". In: Ties in marriage and family. Research methods. 50-106. ed. Mieczysław Plopa, Kraków; Impuls, 2008.

Paleczny, Tadeusz. Interpersonalne stosunki międzykulturowe. Kraków: Publisher of the Jagiellonian University, 2007.

Sowa-Behtane, Ewa. Rodziny wielokulturowe. Kraków: WAM Publishing House, 2016.

Welsch, Wolfgang. "Transculturalism. A new concept of culture". In: Philosophical contexts of the concept of transversal reason. Around the concept of Wolfgang Welsch. 204-216. ed. Robert Kubicki, Poznań: Humanior Foundation Publisher, 1998. 
